\title{
A Multivariate Statistical Approach to Compare Fringe Benefits Between Public and Private Sector Workers
}

\author{
Josefa Ramoni-Perazzi, (Email: jramoni@ula.ve), University of the Andes, Venezuela
}

\begin{abstract}
This study relies on multivariate statistical analysis applied to the Health and Retirement Study (1992-2002) to approach the issue of public/private compensation differences. Particularly, principal components are used to uncover the internal structure of relationships among demographic variables, while multiple correspondence analysis is used to describe and compare wages and fringe benefits between the two sectors. Results indicate the public sector compensates more its workers, not only by offering higher wages but also better non-wage monetary benefits.
\end{abstract}

\section{INTRODUCTION}

$\mathrm{n}$ the last decades many researchers have attempted to compare compensations between the public and private sector in the United States, usually concluding that the public sector pays compensations above those offered in the private sector. This paper examines the issue of public/private compensation differences in a totally different way, by using multivariate statistical analysis to the Health and Retirement Study (HRS, 1992-2002) in order to uncover the internal structure of relationships among variables.

All other things being equal, public sector workers should receive compensation comparable to those received by similar private sector workers performing similar jobs. If it is true that public sector workers are overcompensated compared to similar private sector workers, such a premium can be considered as a rent, since it exceeds what is necessary to attract and retain the labor force this sector requires.

It is not easy to account for non-wage benefits since they are offered in many different combinations, and most often the information is simply not available or cannot be translated into dollars, making the compensation comparison even more difficult. That may explain why most of the literature at this regard limits the analysis to the wage comparison. The HRS data set has the advantage of offering information regarding demographic characteristics and fringe benefits for a very homogeneous population, characteristic that is important when comparing different groups, as is the case in this study.

Multivariate statistical analysis can be applied to identify relationships among variables, based on the correlation among them. Due to the nature of the variables, the demographic characteristics were analyzed through principal components analysis, while wage and non-wage compensation are analyzed through multivariate correspondence analysis.

Results suggest that workers in the public sector tend to have higher levels of education, tenure and training and are paid higher wages. These workers are usually married, white, with relatively smaller families. Older workers are more likely to be veterans, are usually men, unionized, and tend to have lower levels of education and training. Women seem to earn lower wages compared to men. The public sector shows a higher proportion of workers covered by health insurance and pension plans offered by the employer or the union, more days of paid sick leave and more weeks of paid vacation. However, it has to be said that workers in this sector not only enjoy better fringe benefits, but also have to contribute more to finance them. Based on the results discussed above it can be concluded that public 
sector workers enjoy both wage and non-wage advantages, compared to the private sector, differential than could be the result of the role of unions or due to political issues.

\section{LITERATURE REVIEW}

For many years, the idea that earnings paid to public sector workers were far above those received by their private counterparts generated a debate about the size of government, the efficiency of the public wage-setting system, its contribution to fiscal stress and the proper use of tax funds.

Efficiency and equity principles indicate that government should pay no more than what is necessary to attract a sufficient supply of workers. But even though economic theory indicates that both sectors should pay the same for similar jobs, several reasons can explain compensation differences between both sectors. First, the wagesetting system in public sector is not the same as the one applied in private industry, since the former lacks of the information provided by the market as the result of the nature of the services it provides. Second, the bargaining power of unions also differs across sectors. Unions have the potential to control the labor supply in such a way as to influence compensation and push them above the competitive level. However, it is well known that their bargaining power is different in public and private sectors. Evidence regarding the influence of unions on compensation is ambiguous. Some studies indicate that public sector unions have greater ability to raise the relative wage. Others indicate that given their relatively shorter history, public sector unions are not as powerful as private sector unions, and since they are restricted by law, their influence on wages is limited, but not their influence on non-wage compensations and non-pecuniary attributes of employment, especially job security and access to training programs. However it is clear that there is an increasing participation of public sector workers in unions, and a decreasing unionization tendency among private sector workers. Finally, there may exists spurious compensation differences due to technical problems. Empirical researchers have used data and/or techniques that can be inadequate to test the hypothesis of no compensation differences. Given the difficulties in answering the question about whether comparable workers performing comparable jobs are compensated the same in the public sector and in the private sector, the majority of the studies have been limited to comparing wages, ignoring other aspects of total compensation such as non-wage pecuniary benefits or fringe benefits. ${ }^{i}$

Comparing fringe benefits across sectors is more difficult than comparing wages due to differences in options, and lack of information. The proliferation of different fringe benefit combinations make the valuation of plans difficult, and an accurate comparison impossible. Each plan treats individuals differently depending on the sector of employment, age, tenure, etc. Moreover, not all benefits can be translated into dollars, as is the case of job security, working conditions, probability of promotion, and access to on-the-job training programs.

According to Foster (1997), the average total cost for employee compensation is larger in the public sector than in the private sector ( $\$ 25.73$ versus $\$ 17.49$ per hour), but the proportion of these costs due to benefits is very similar (about 30 percent). The incidence of these employer-provided benefits however is different and difficult to compare. During the 1990s, for example, benefits such as medical and dental care, paid sick leave, and life insurance were more common among public sector employees, while benefits for paid holidays and vacations were more common among private sector workers. The differences in costs and provision of benefits reflect differences in occupations, and make it difficult to compare them between sectors.

A more detailed analysis can be done by selecting specific benefits, retirement benefits being among the most important. In fact, pensions represent 7.4 percent of the total benefits in the public sector and 3.1 percent in the private sector. In her study, Foster (1997) compares pension plans between private, public, and state sectors. Using data from the EBS, she observes that even though almost all full-time workers in both sectors are covered by at least one pension plan and Social Security, there are substantial differences in these plans. In the public nonfederal sector for example, 72 percent of the workers contribute to the costs of their own pension plans, contributing about 6 percent of their earnings, while 97 percent of private sector workers enjoy benefits paid entirely by employers. However, the former group receives benefits that are larger compared to those in the private sector, are more likely to participate in cost-ofliving adjustments, and can retire earlier with unreduced pensions (minimum retirement age is 55 in the public sector and 65 in the private sector). 
Many authors have recognized that the failure to account for differences in fringe benefits, and other nonpecuniary benefits tends to bias the wage differential conclusions [Brown (1980); Bellante and Long (1981); Krueger (1987); Moulton (1990)]. Nonetheless only a few studies have attempted to examine wage differentials adjusted for the provision of such benefits. One approach compares quit rates in both the public and private sectors, assuming that lower quit rates in the former can be taken as evidence that government employees receive higher compensation, since they consider differences not only in wages, but also in benefits and working conditions. Ehrenberg and Schwarz (1986) suggest that better monetary and non-monetary conditions of employment should lead to lower quit rates, which are lower in the public than in the private sector.

Even though studies in general show lower quit rates in the public sector, the interpretation of these results may not always be valid. Gregory and Borland (1999) point out some reasons for this possible misinterpretation. First, optimal rates of turnover may differ between the private sector and the public sector. There exists evidence that worker turnover rates decrease with the size of establishment, and average establishment size is larger in the public sector than in the private one. Second, these studies do not control for job characteristics and amount of specific training, which is known to have a negative relationship with the probability of leaving a job. Finally, differences in the level and timing of pensions can account for these differences. Long (1982) shows that public workers are less likely to quit. Ippolito (1987) argues that the low quit rate in the federal sector is due to substantial pension losses imposed on workers who quit early. Cox (1996) on the other hand, sees the relative higher federal employee tenure as an indicator that federal employee compensation is above the market rate.

Another approach analyzes queues: if individuals perceive government employment relatively more attractive, one could expect longer queues of applicants for government openings than for private sector jobs. In these models, a worker's utility is a function of observable employment characteristics and public/private wage differentials. An applicant will choose to work in the sector providing the highest level of utility. Studies of this sort generally support the hypothesis of a higher number of applicants for the majority of the jobs offered in the public sector [Krueger (1987); Mohanty (1994)].

Some studies have examined specific components of fringe benefits or particular job attributes. Quinn (1982) compares pension plans between different levels of government and the private sector. Using data from the 1969 Retirement History Study that includes information on pension plans and Social Security records, he runs regressions of wealth levels on years of job tenure, final wage rate and sector dummy variables, in both linear and logarithmic form. Wealth levels are adjusted for employers' contributions, Social Security coverage and inflation protection. ${ }^{\text {ii }} \mathrm{He}$ concludes that pensions are more attractive in the public sector than in the private sector, especially for federal and state employees.

Wiatrowski (1988) compares paid time-off, insurance and retirement benefits in private industry with those offered in state and local governments between 1979 and 1987. Using data drawn from the EBS, some of his most significant findings indicate that paid vacations are granted to almost all full-time private sector workers, but only to 75 percent of government employees. However, the last group is more likely to enjoy multiple-purpose annual leave plans. Public employees are also more likely to participate in HMO plans, which offer more complete home health care, and physical examinations and surgical benefits. However they also contribute more to these plans compared with private industry workers. The amount of coverage and the level of employer contribution appear to decrease with level of government (Blostin, et al. 1988). Public pension plans tend to be more generous than those offered in the private sector because employees' contributions are higher. Similar results about pensions are obtained by Lovejoy (1988) and Mitchell and Smith (1994).

Heywood (1991) compares the public and private provision of what he considers are the five major fringe benefits (retirement programs, health insurance, life insurance, vacation leave and sick leave). Using data from the 1977 Quality of Employment Survey, he regresses a probit model for each of these fringe benefits using experience, education, race, sex, SMSA, tenure, trade school attendance, regional dummy, plant size, and union status as explanatory variables. Additionally, he uses a dummy variable to identify government workers grouped together or disaggregated into federal, state, and local sectors. His results show that education, tenure, plant size and union membership increase the probability of benefit provision. Women have a smaller yet significant chance of provision, 
while race is not significant. The government employment variable is highly significant, increasing the probability of receiving all the benefits, except health insurance, which says that government employees enjoy substantially larger compensations than private workers. Within the government sector, the provision of fringe benefits is particularly strong at the local level.

A broader comparison is undertaken by Braden and Hyland (1993). They observe that public sector workers' average hourly total compensation is about $\$ 23.50$, almost 50 percent higher than private industry workers $(\$ 16.14)$. Two thirds of this gap is due to wage differences, and one third corresponds to differences in benefits. ${ }^{\text {iii }}$ The difference in total compensation is particularly large for service workers (95.5 percent), while for white-collar workers and bluecollar workers the difference is approximately 40 percent and 13 percent, respectively. However, when disaggregating the occupations even further, compensation costs appear to be similar for industry activities that are common in both sectors. Therefore, the broad occupational disparities in total compensation are again the result of aggregation bias. They reflect the differences in the composition of those jobs within the groups above mentioned. For example, among white-collar workers (who constitute 68 percent of the government labor force and 51 percent in the private sector), 56 percent of them are professional and technical in the public sector, compared to just 24 percent in the private sector. Using data from the 1986 and 1994 ECI, Pierce (1997) compares wages and total compensation in each percentile of the wages and compensation distributions. He finds that the differential is larger for total compensation, especially at the bottom of the distribution.

Given the complexity involved and the variety of fringe benefit packages, only a few studies have applied the traditional methodology used to compare wages to the case of total compensation. In his wage equation, Brown (1980) introduces fringe benefits as the ratio of nonwage compensation to wages.

Bellante and Long (1981) address the problem of adjusting wage differentials for nonwage compensations and other nonpecuniary job attributes in each sector. They use Smith's (1977) regression results to construct indexes to compare the return to human capital among private, federal, state and local sectors workers. These indexes are then adjusted by the proportion of fringe benefits and the probability of unemployment in each sector. Their findings confirm that the total compensation for public workers at all levels of government is higher than that of comparable workers in the private sector.

Even though it is difficult to compare total compensation in each sector, the advantages enjoyed by government workers can be summarized as follows (Cox and Brunelli, 1994): more generous fringe benefits; more paid vacations days, holidays, and personal days off; more sick time off; value of excess paid benefits free from federal and state income taxes, as well as exemption from state income tax; larger annual compensations increases and lower productivity, with shorter work weeks; greater job security; generous severance pay; earlier retirement, including routine pension benefit increases and paid retiree health care.

\section{METHODOLOGY}

This study applies multivariate statistical analysis techniques to the information provided by the Health and Retirement Study for the period 1992 - 2002 to compare compensation between the public and private sectors.

The Health and Retirement Study is a nation wide longitudinal study that consists of waves or cohorts interviewed every other year focusing on individuals aged 51-61 at baseline (1992). Its main goal is to collect information on demographics, labor force status, health, retirement, and working conditions at the individual level. Excluded from the sample were those individuals working in the agricultural sector, those self-employed or in the armed forces as well as those working less than 10 or more than 80 hours a week or who earned less than half of the minimum hourly wage in effect at the time of the interview. ${ }^{\text {iv }}$ The final data set contains 22,267 individuals, $8.87 \%$ of them working in public administration and the remaining $91.13 \%$ employed in the private sector.

Multivariate statistical analysis (MSA) can be applied whenever the data sets include simultaneous measurements on many variables and for many individuals or units, since the relationships among them are not easily discernible by common statistical measures. One of the main features of MSA resides in the fact that it reduces the 
number of variables by identifying relationships among them, and grouping them into new variables called factors, based on the correlation among such variables and their dispersion. By doing so, the phenomenon under study is presented as simply as possible, without sacrificing valuable information. In this study, I attempt to identify the internal structure of the data and their links through multivariate correspondence analysis (MCA) and principal components analysis (PCA).

Principal components explain the variance-covariance structure of the data through linear combinations of the variables, in order to reduce the data dimensionality and to facilitate its interpretation. Therefore, even if the data contain $n$ observations for $p$ variables, almost all the information is collected in $k$ 'principal components', for $\mathrm{k}<\mathrm{p}$, so that the final sample set contains nxk observations. Since PCA often reveals unsuspected relationships among variables and allows interpretations that would not usually be reached, it is considered a necessary step in the analysis of the structure of the public and private sector.

As stated, PCA is very helpful in describing continuous variables, for which Euclidean distance can be calculated. However, the HRS contains many qualitative (nominal and ordinal) variables, so that an additional procedure for depicting the structure behind the data is necessary. Multivariate correspondence analysis is a descriptive/exploratory technique designed to analyze multi-way tables containing some measure of correspondence between the rows and columns. This analysis provides a graphical procedure designed to represent associations among continuous and discrete variables in a low-dimensional space. MCA is based on Chi-2 distances, which is a modification of a natural Euclidean distance applicable to any kind of variable, continuous and/or discrete. In other words, MCA is equivalent to applying PCA on variables for which Chi-2 distance has been defined. The results provide information that allows one to explore the structure of variables included in the table.

\section{RESEARCH RESULTS}

\section{Demographic characteristics}

The general literature describes the public sector as characterized by having, on average, an older population compared to the private sector, with relatively higher levels of education, a higher proportion of minorities (supposedly due to a more strict application of anti-discrimination policies), a higher but declining trend to unionize, less likely to quit or shift jobs and therefore with longer tenure (since this sector offers more job stability and better working conditions), and earning higher wages. The HRS sample set for the period considered in this study seems to support this general characterization of the public sector population, at least partially.

The statistics shown in Table 1 indicate that public sector workers are slightly younger than private workers, with a not significantly higher participation of women and nonwhite workers in the private sector. Public sector workers tend to have higher levels of education (13.79 years of schooling, versus 12.61 years in the private sector). Additionally, public sector workers show relatively longer tenure, accumulate more hours of training and on average work more hours a week. The proportion of veterans working for the private sector is high ( 25.40 percent), but still lower than the level observed in public administration (31.17 percent). A similar pattern is observed for the case of the union status variable, indicating that public sector workers are more likely to be covered by a union.

Against the general presumption that married workers prefer to work in the public sector since it is more perceived as offering greater job stability, the HRS shows that risk adverse workers, as well as married workers with large families tend to work in the private sector, although the differences between the two sectors are not significant. Based on this sample, workers leaving in the South and West census regions are more likely to work in the public sector.

The previous description provides a sketch of the populations being examined. However, the relationships among variables are not easily shown by common statistical measures, especially for large data sets including many variables and many individuals. Multivariate statistical analysis, particularly principal components (PCA) ${ }^{v}$ is used to reveal the internal structure of the data, by identifying linear combinations of the demographic variables and grouping them into components, based on the correlation among such variables and their dispersion. Graphically, these 
components are represented on the axes, and can be interpreted as follows: Variables grouped on the same side of one axis are positively related to each other, and negatively related to the variables on the other side of the same axis.

Table 1: Summary of demographic characteristics

\begin{tabular}{|c|c|c|c|c|}
\hline \multicolumn{2}{|r|}{ Variables definition } & Values & Private & Public \\
\hline CENREG & $\begin{array}{l}\text { Census region division (\%): Northeast (1); } \\
\text { Midwest (2); South (3); West (4) }\end{array}$ & $\begin{array}{l}1 \\
2 \\
3 \\
4\end{array}$ & $\begin{array}{l}18.47 \\
26.00 \\
40.04 \\
15.49\end{array}$ & $\begin{array}{l}17.20 \\
23.18 \\
42.52 \\
17.10\end{array}$ \\
\hline EDUCTG & $\begin{array}{l}\text { Level of education (\%): HS dropout (1); HS } \\
\text { (2); some college (3); college and more (4) }\end{array}$ & $\begin{array}{l}1 \\
2 \\
3 \\
4\end{array}$ & $\begin{array}{l}36.14 \\
29.54 \\
20.80 \\
13.52\end{array}$ & $\begin{array}{l}20.55 \\
29.70 \\
28.90 \\
20.85\end{array}$ \\
\hline FULTME & Fulltime working condition $(\%)$ : yes $(1) ;$ no( $(0)$ & $\begin{array}{l}0 \\
1 \\
\end{array}$ & $\begin{array}{l}21.36 \\
78.64\end{array}$ & $\begin{array}{l}13.06 \\
86.94\end{array}$ \\
\hline GENDER & Gender $(\%)$ : male $(1)$; female $(0)$ & $\begin{array}{l}0 \\
1 \\
\end{array}$ & $\begin{array}{l}52.98 \\
47.02\end{array}$ & $\begin{array}{l}52.07 \\
47.93\end{array}$ \\
\hline HEALTH & $\begin{array}{l}\text { Self-reported health status (\%): excellent / } \\
\text { good (1); otherwise }(0)\end{array}$ & $\begin{array}{l}0 \\
1\end{array}$ & $\begin{array}{l}12.82 \\
87.18\end{array}$ & $\begin{array}{c}7.74 \\
92.26\end{array}$ \\
\hline MARTST & Marital status (\%): married (1); otherwise (0) & $\begin{array}{l}0 \\
1\end{array}$ & $\begin{array}{l}21.09 \\
78.91\end{array}$ & $\begin{array}{l}20.70 \\
70.30\end{array}$ \\
\hline RACE & Race $(\%)$ : white $(1)$; otherwise $(0)$ & $\begin{array}{l}0 \\
1\end{array}$ & $\begin{array}{l}18.17 \\
81.83\end{array}$ & $\begin{array}{l}17.05 \\
82.95\end{array}$ \\
\hline RISKAV & $\begin{array}{l}\text { Risk aversion (\%): risk averse (1); otherwise } \\
(0)\end{array}$ & $\begin{array}{l}0 \\
1\end{array}$ & $\begin{array}{l}40.78 \\
60.22\end{array}$ & $\begin{array}{l}40.23 \\
59.77\end{array}$ \\
\hline TRAING & $\begin{array}{l}\text { 100+ hours of on-job-training }(\%) \text { : no }(0) \text {; yes } \\
(1) ; \text { more than } 12 \text { years }(2)\end{array}$ & $\begin{array}{l}0 \\
1 \\
2\end{array}$ & $\begin{array}{l}33.45 \\
24.44 \\
42.11\end{array}$ & $\begin{array}{l}13.82 \\
27.60 \\
58.58\end{array}$ \\
\hline UNION & Union status $(\%)$ : yes $(1)$; no $(0)$ & $\begin{array}{l}0 \\
1 \\
\end{array}$ & $\begin{array}{l}76.25 \\
23.75\end{array}$ & $\begin{array}{l}70.41 \\
29.59\end{array}$ \\
\hline VETERN & Veteran status (\%): yes (1); no (0) & $\begin{array}{l}0 \\
1\end{array}$ & $\begin{array}{l}74.60 \\
25.40\end{array}$ & $\begin{array}{l}68.83 \\
31.17\end{array}$ \\
\hline AGE & Age (years) & $\begin{array}{l}\text { Mean } \\
\text { s.d }\end{array}$ & $\begin{array}{c}56.61 \\
5.56\end{array}$ & $\begin{array}{c}55.62 \\
5.83\end{array}$ \\
\hline CHILDN & Number of children & $\begin{array}{c}\text { Mean } \\
\text { s.d }\end{array}$ & $\begin{array}{l}3.29 \\
1.94 \\
\end{array}$ & $\begin{array}{l}3.03 \\
1.86 \\
\end{array}$ \\
\hline EDUYRS & Years of education & $\begin{array}{c}\text { Mean } \\
\text { s.d }\end{array}$ & $\begin{array}{c}12.61 \\
2.91\end{array}$ & $\begin{array}{l}13.79 \\
2.270\end{array}$ \\
\hline HRSWEK & Hours worked per week & $\begin{array}{c}\text { Mean } \\
\text { s.d }\end{array}$ & $\begin{array}{l}39.80 \\
11.37\end{array}$ & $\begin{array}{c}40.75 \\
9.57\end{array}$ \\
\hline TENURE & $\begin{array}{l}\text { Length of service with current employer } \\
\text { (years) }\end{array}$ & $\begin{array}{c}\text { Mean } \\
\text { s.d }\end{array}$ & $\begin{array}{l}14.12 \\
11.06 \\
\end{array}$ & $\begin{array}{l}15.27 \\
10.87\end{array}$ \\
\hline $\mathrm{N}$ & Sample size & & 20,291 & 1,976 \\
\hline
\end{tabular}

The PCA, not discriminated by sector, shown in Figure 1 represents the first two components obtained for the HRS data set. The first component (horizontal axis), which explains 18.85 percent of the total variability of the variables, associates sector of employment (SECTOR) and wages (WAGEHR) to human capital variables such as education (EDUYRS), training (TRAING), and tenure (TENURE), as well as union status (UNION), full/part -time condition (FULTME), and veteran condition (VETERN). These variables are strongly opposed to gender (GENDER), and weakly opposed to other workers' characteristics namely marital status (MARTST), race (RACE), and family size (CHILDN). This can be interpreted by saying that women earn lower wages, compared to men. Also, workers with higher levels of human capital accumulation (education, and training) are paid higher wages and tend to work in the public sector. These workers tend to be married, white, with relatively smaller families although these variables are not strongly related to the others. Older workers tend to be veterans and to be represented by unions. On the other 
hand, the second component (vertical axis on Figure 1), which explains 14.00 percent of the total variability, opposes GENDER, EDUYRS and TRAING to VETERN and AGE. This means that older workers are more likely to be veterans, are usually men and tend to have lower levels of education and training. ${ }^{\mathrm{vi}}$

\section{Figure 1: General demographic characteristics}

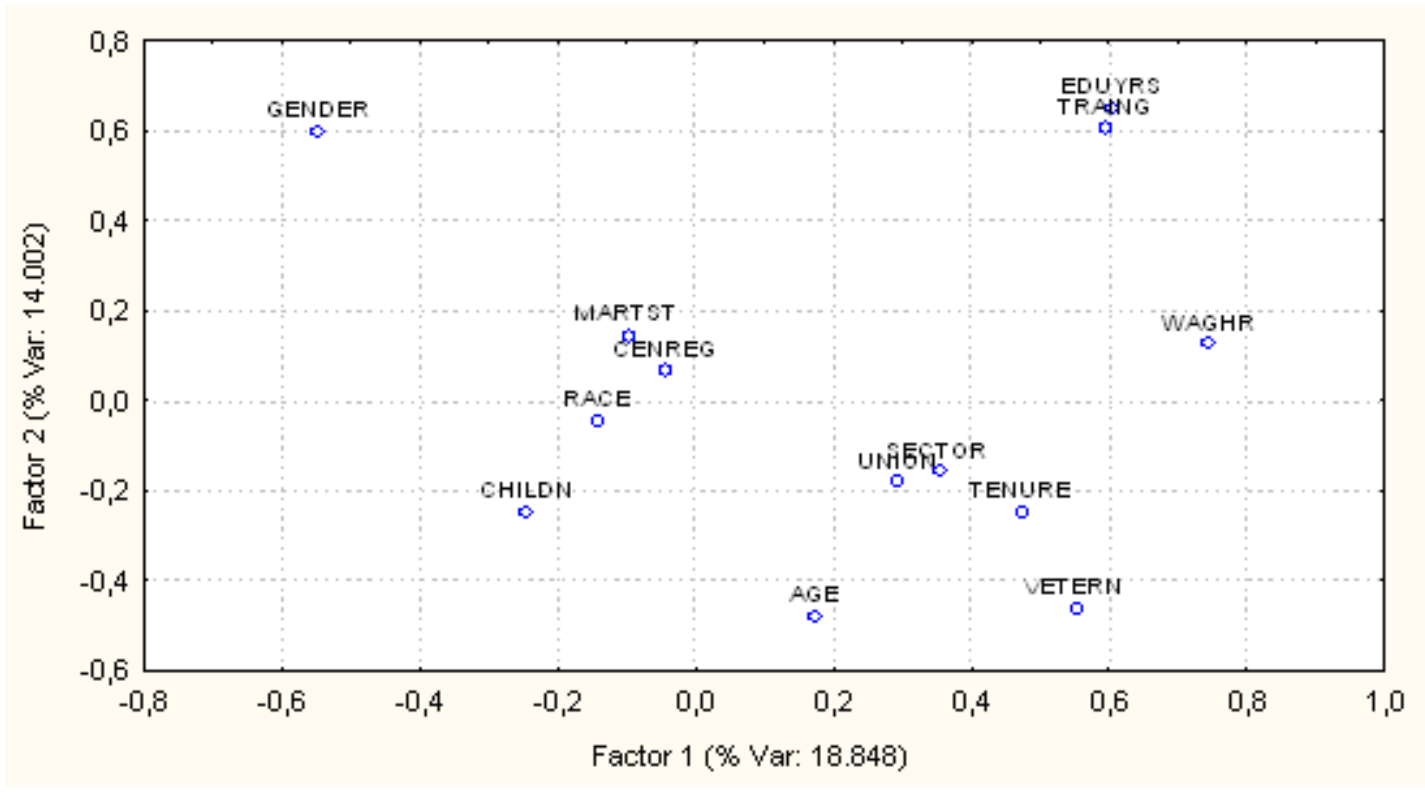

\section{Fringe benefits}

The studies comparing public and private pension plans tend to indicate that public sector workers receive larger pension benefits, with more possibility of cost-of-living adjustments and of early retirement with full pensions, primarily because the contribution of public sector workers to these plans is higher. [Quinn (1982); Blostin et al. (1988); Lovejoy (1988); Wiatrowski (1988); Mitchell and Smith (1994); Foster (1997)]. This may be the reason why pension benefits seem to make up a larger share of total compensation in the public sector than in the private sector. ${ }^{\text {vii }}$

The proper comparison of pension plans between the two sectors should consider the type of formula used to compute benefits, the age and years of service required for benefit eligibility, and the employers' financial contribution to these plans. The pension plan information provided by the HRS indicates that 87.65 percent of public sector workers have pension plans offered through employers or unions, other than Social Security, ${ }^{\text {viii }}$ compared to only 63.94 percent in the private sector (See Table 2). According to the BLS, public sector workers with a pension plan and the required years of service can retire at ages under 60 , most commonly 55 , while private sector workers covered by pension plans usually can retire later, most commonly at ages 62 or 65 .

The type of pension plan also varies significantly between the two sectors. According to the HRS data, Defined benefit pension plans (Plan A) are more prevalent in the public sector. In fact, more than 87 percent of the public sector workers have this type. In defined benefit plans the benefits or retiree annuities are based on a formula involving age, years of service and salary, but the employer's contribution to the plan is not subject to a predetermined formula. ${ }^{\text {ix }}$ Defined contribution plans are more frequent among private sector workers. In defined contribution plans, the final benefit received by the retiree is not specified, since it depends on the contributions and investment earnings at the time of retirement. This type of plan includes savings and thrift plans, such as 401-k, 403-b. In the HRS, defined 
contribution plans as well as other benefits such as stock ownership plans, and profit-sharing plans are lumped together in what is defined as pension plan B.

The structure of the workers' financial contribution to pension plans also varies between the two sectors. Among HRS workers with defined benefit pension plans, 69.30 percent of the private sector workers do not contribute to the plan, compared to only 27.28 percent in the public sector. Lovejoy (1988) estimates that the proportion of workers contributing to type-A plans averages 78 percent in the public sector, but only 6 percent in the private sector. She also finds that workers in the public sector are more likely to enjoy cost-of-living adjustments of their annuities. A similar pattern is observed for the case of defined-contribution pension plans. She concludes that public pension plans tend to be more generous than those offered in the private sector, at least partly because the employees' contributions are higher.

Table 2: Summary of fringe benefits

\begin{tabular}{|c|c|c|c|c|}
\hline \multicolumn{3}{|c|}{ Variables definition } & \multicolumn{2}{|c|}{ Sector } \\
\hline & Pension Plans (\%) & Values & Private & Public \\
\hline $\mathrm{ABA}$ & $\begin{array}{l}\text { Age start receiving benefits in pension plan: } \leq 60 \text { years } \\
(1) ;>60 \text { years }(2)\end{array}$ & $\begin{array}{l}1 \\
2\end{array}$ & $\begin{array}{l}35.30 \\
64.71\end{array}$ & $\begin{array}{l}53.88 \\
46.13\end{array}$ \\
\hline NPP & Number of pension plans & $\begin{array}{c}1 \\
2 \\
3+\end{array}$ & $\begin{array}{c}71.93 \\
23.64 \\
4.41\end{array}$ & $\begin{array}{c}67.11 \\
31.54 \\
1.34\end{array}$ \\
\hline PEN & Pension offered by employer / union: yes (1); no(0) & $\begin{array}{l}0 \\
1\end{array}$ & $\begin{array}{l}36.06 \\
63.94\end{array}$ & $\begin{array}{l}12.35 \\
87.65\end{array}$ \\
\hline TYP & Type of pension plan: plan A (1); plan B (2); both (3) & $\begin{array}{l}1 \\
2 \\
3\end{array}$ & $\begin{array}{c}60.57 \\
36.18 \\
3.25\end{array}$ & $\begin{array}{c}82.43 \\
14.53 \\
3.04\end{array}$ \\
\hline WCA & $\begin{array}{l}\text { Worker's contribution to pension plan A: nothing }(0) ; \leq \\
5 \%(1) ;>5 \% \text { and } \leq 10 \%(2) ;>10 \%(3)\end{array}$ & $\begin{array}{l}0 \\
1 \\
2 \\
3 \\
\end{array}$ & $\begin{array}{c}69.30 \\
11.37 \\
16.37 \\
2.96\end{array}$ & $\begin{array}{l}27.28 \\
14.79 \\
43.20 \\
14.73\end{array}$ \\
\hline WCB & $\begin{array}{l}\text { Worker's contribution to pension plan B: nothing }(0) ; \leq \\
5 \%(1) ;>5 \% \text { and } \leq 10 \%(2) ;>10 \%(3)\end{array}$ & $\begin{array}{l}0 \\
1 \\
2 \\
3\end{array}$ & $\begin{array}{l}41.14 \\
24.29 \\
23.09 \\
11.49\end{array}$ & $\begin{array}{c}3.57 \\
28.57 \\
57.14 \\
10.71\end{array}$ \\
\hline \multicolumn{5}{|c|}{ Health Insurance (\%) } \\
\hline $\mathrm{COV}$ & $\begin{array}{l}\text { Covered by health insurance provided through the } \\
\text { employer: yes }(1) ; \text { no }(0)\end{array}$ & $\begin{array}{l}0 \\
1\end{array}$ & $\begin{array}{l}36.32 \\
63.68\end{array}$ & $\begin{array}{l}19.35 \\
80.65\end{array}$ \\
\hline DIS & Long term disability coverage offered: yes (1); no (0) & $\begin{array}{l}0 \\
1\end{array}$ & $\begin{array}{l}43.36 \\
56.64\end{array}$ & $\begin{array}{l}37.69 \\
62.31\end{array}$ \\
\hline NHI & Number of health insurance plans & $\begin{array}{c}1 \\
2+\end{array}$ & $\begin{array}{c}90.45 \\
9.55\end{array}$ & $\begin{array}{l}87.85 \\
12.15\end{array}$ \\
\hline PAY & $\begin{array}{l}\text { Who pays health insurance plan(s): entirely by worker } \\
\text { (1); entirely by employer (2); part by worker, part by } \\
\text { employer ( } 3 \text { ) }\end{array}$ & $\begin{array}{l}1 \\
2 \\
3\end{array}$ & $\begin{array}{c}9.68 \\
37.93 \\
52.39\end{array}$ & $\begin{array}{c}8.53 \\
36.02 \\
55.45\end{array}$ \\
\hline SUP & Supplemental coverage available: yes $(1) ;$ no $(0)$ & $\begin{array}{l}0 \\
1\end{array}$ & $\begin{array}{l}83.83 \\
16.17\end{array}$ & $\begin{array}{l}85.59 \\
14.41\end{array}$ \\
\hline \multicolumn{5}{|c|}{ Other Benefits } \\
\hline INF & $\begin{array}{l}\text { Probability of wage adjusted by inflation (\%): yes (1); } \\
\text { no }(0)\end{array}$ & $\begin{array}{l}0 \\
1\end{array}$ & $\begin{array}{l}44.70 \\
55.29\end{array}$ & $\begin{array}{l}39.35 \\
60.65\end{array}$ \\
\hline SIC & Number of days of paid sick leave & $\begin{array}{l}\text { Mean } \\
\text { s.d. }\end{array}$ & $\begin{array}{c}6.71 \\
10.38\end{array}$ & $\begin{array}{c}12.37 \\
9.45\end{array}$ \\
\hline VAC & Number of weeks of paid vacation & $\begin{array}{c}\text { Mean } \\
\text { s.d. }\end{array}$ & $\begin{array}{l}2.61 \\
2.21\end{array}$ & $\begin{array}{l}3.55 \\
1.87\end{array}$ \\
\hline
\end{tabular}


According to the BLS, health insurance is another benefit which represents a high proportion of the total employee compensation (7.9 percent in the public sector and 6.1 percent in the private one). Table 2 indicates that more than 80 percent of the public sector workers are covered by health insurance provided by the employer, compared to only 63.68 percent in the private sector. Employers and employees usually share the cost of these health insurance plans, with the family plan being the most common at all sectors, especially at the federal level. However, the general literature suggests that public sector workers tend to contribute more to these plans compared to private sector workers, and that the coverage and the fraction of employer contribution appear to decrease with the level of government (Blostin, et al. 1988). Also, public sector workers are more likely to have long-term disability coverage and to participate in HMO plans, which offer better benefits. Therefore it can be said that, as is the case with pension plans, public sector workers enjoy better health insurance benefits, but also contribute more to their cost.

Figure 2 presents the MCA that summarizes the provision of some fringe benefits in the public and the private sector. The public sector (SCT1, at the right) is associated with higher values of the variables, meaning that in this sector there is higher proportion of workers covered by health insurance (COV) and pension plans (PEN), and enjoying more days of paid sick leave(SIC) and more weeks of paid vacation (VAC) compared to the private sector (SCT0, at the left). ${ }^{\mathrm{x}}$ In addition, the public sector is associated with higher levels of wages (WG) ${ }^{\mathrm{xi}}$ meaning that workers this sector not only enjoy better fringe benefits, but also are paid higher wages than those paid to private sector workers. According to the BLS, over the period between 1992 and 2002 the percent of total compensation due to fringe benefits is 27.86 percent in the private sector and 29.96 percent in the public sector. ${ }^{\text {xii }}$

Based on the results discussed above it can be concluded that public sector workers enjoy both wage and non-wage advantages, compared to the private sector. There are two main reasons that explain why greater fringe benefits should be expected in the public sector.

Figure 2: Fringe benefits by sector

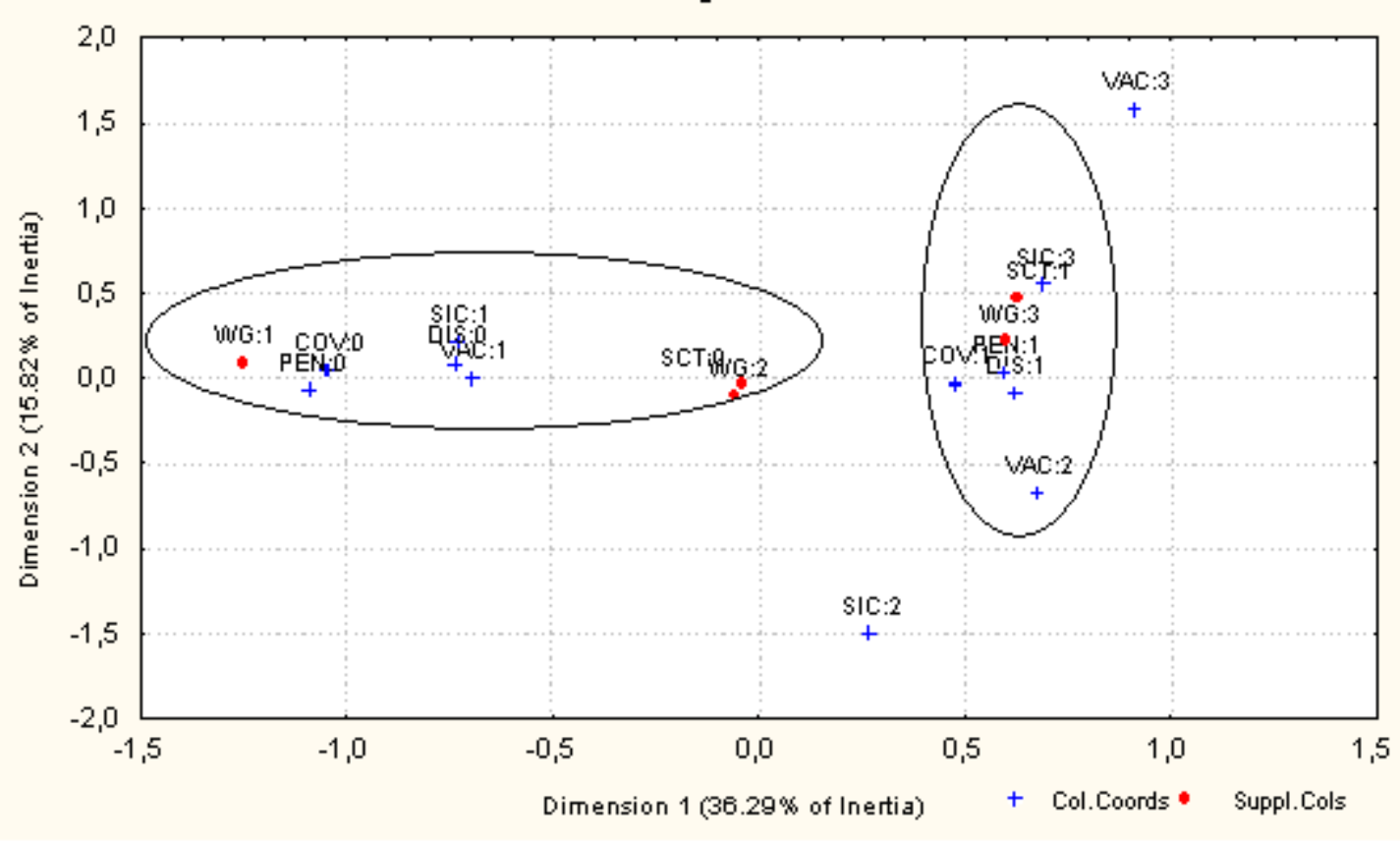




\section{CONCLUSIONS}

This study examines whether or not public sector workers are paid higher compensation compare to private sector workers, by analyzing the correlations among variables through multivariate statistical analysis. The results indicate that public sector workers tend to have higher levels of education, tenure and training, along with higher wages. This is obvious since all these human capital factors are known to have a positive impact on wages. Findings also show that workers in this sector are more likely to have their wages adjusted by the inflation.

With respect to fringe benefits, the results indicate that the higher wages paid in the public sector are accompanied by better non-wage monetary benefits. In fact, public sector workers enjoy more days of paid sick leave and vacation, and are more likely to be covered by a health plan and a pension plan offered by the employer or union, with early retirement age. These better benefits are possible in part because public sector workers contribute more to finance them, and in part due to the bargaining power of unions, to which public sector workers show a higher tendency to participate in. Unions in the public sector are believed to influence more the provision and the level of either fringe benefits and non-pecuniary attributes of employment, especially job security and access to training programs than wages themselves. Finally, an additional explanation for the higher non-wage compensation in the public sector can be pointed out. Unlike the cost of a wage increase that immediately affects taxpayers, the cost of fringe benefits can be delayed. By offering this combination of visible benefits today and diffuse costs tomorrow, politicians can maximize their probability of re-election, and leave the cost of such a policy to a future government. The high incidence of generous pension plans at the local level reported by the general literature seems to support this idea.

\section{REFERENCES}

1. Bellante, Don and James E Long, The Political Economy of the Rent-Seeking Society: The Case of Public Employees and Their Unions. Journal of Labor Research, Vol. 2, No. 1, pp 1-14, Spring 1981.

2. Blostin, Allan. P.; Thomas P. Burke; and Lora M Lovejoy. Disability and Insurance Plans in the Public and Private Sectors. Monthly Labor Review, pp 9-14, December 1988.

3. Braden, Bradley R. and Stephanie L. Hyland Cost of Employee Compensation in Public and Private Sectors. Monthly Labor Supply, pp 14-21, May 1993.

4. Brown, Charles. Equalizing Differences in the Labor Market. Quarterly Journal of Economics, Vol. 94, No. 1, pp 113-134, February 1980.

5. Cox, Wendell. U.S. Federal Employee Pay is Above Market. The Public Purpose, Vol. 3, pp 1-7, March 1996.

6. Cox, Wendell and Samuel A. Brunelli. America's Protected Class: The Excess Cost of Government Employment in U.S. American Legislative Exchange Council, Washington, D.C., 1994.

7. Ehrenberg, Ronald G. and Joshua L. Schwarz. Public-Sector Labor Markets. In Handbook of Labor Economics, vol. 2, edited by O. Ashenfelter and R. Layard, chapter 22, Elsevier Science Publishers Bv, 1986.

8. Foster, Ann C. Public and Private Sector Defined Benefit Pensions: A Comparison. Compensation and Working Conditions, pp 37-43, Summer 1997.

9. _. Private Sector Employee Benefits, 1996-97. Compensating and Working Conditions. Pp 17-22, Summer 2000.

10. Gregory, Robert G. and Jeff Borland. Recent Developments in Public Sector Labor Markets. In Handbook of Labor Economics, vol. 3, edited by O. Ashenfelter and D. Card, chapter 53, Elsevier Science Publishers Bv, 1999.

11. Heywood, John S. Government Employment and the Provision of Fringe Benefits. Applied Economic, Vol. 23, pp 417-423, 1991.

12. Ippolito, Richard. Why Federal Workers Do Not Quit. Journal of Human Resource, Vol. 22, pp 281-299, 1987.

13. Krueger, Alan B. Are Public Sector Workers Paid More than their Alternative Wage? Evidence from Longitudinal Data and Job Queues. Working Paper, no. 225. Industrial Relations Section, Princeton University, 1987. 
14. Long, James E. Are Government Workers Overpaid? Alternative Evidence. Journal of Human Resources, No. 14, pp 41-62, 1982.

15. Lovejoy, Lora M. The Comparative Value of Pensions in the Public and Private Sectors. Monthly Labor Review, pp 18-26, December 1988.

16. Mitchell, Olivia S. and Robert Smith. Pension Funding in the Public Sector. Review of Economics and Statistics, Vol. 76, No. 2, pp 278-290, May 1994.

17. Mohanty, Madhu. Union Premiums in the Federal and Private Sectors: Alternative Evidence from Job Queues. Journal of Labor Research, Vol. 15, No. 1, pp 73-81, 1994.

18. Moulton, Brent R. A Reexamination of the Federal-Private Wage Differential in the United States. Journal of Labor Economics, Vol. 8, No. 2, pp 270-293, April 1990.

19. Pierce, Brooks. Compensation Inequality. Working Paper, no. 323. Bureau of Labor Statistics: Office of Compensation and Working Conditions, June 1997.

20. Quinn, Joseph F. Pension Wealth of Government and Private Sector Workers. American Economic Review, Vol. 72, No. 2, pp 283-287, May 1982.

21. Smith, Sharon P. Government Wage Differentials. Journal of Urban Economics, No. 4, pp 248-271, 1977.

22. Wiatrowski, William J. Comparing Employee Benefits in the Public and Private Sectors. Monthly Labor Review, pp 3-8, December 1988.

\section{ENDNOTES}

${ }^{i}$ The Employment Benefits Survey (EBS) provides a list of all the benefits workers receive, such as paid leave, disability, medical and dental care, life insurance, funeral services, and retirement benefits. For a complete list of benefits and the participation of workers in their costs see Foster (2000).

${ }^{i i}$ Many government pension plans require employee contributions, but this is not a common requirement in the private sector. Almost all private workers and many government employees are covered by Social Security. Federal employees generally have full automatic cost-of-living adjustments, while just six percent of private plans are adjusted.

iii Benefits in the private sector make up 33.2 percent of compensation costs for blue-collar workers, 27.3 percent for white-collar workers, and 24.5 percent for service occupations. In the public sector, these proportions are 35.7 percent, 28.8 percent, and 36.6 percent, respectively.

${ }^{\text {iv }}$ Minimum wage protection was one of the most active issues in 1991. Rates increased under federal law to $\$ 4.25$ per hour in January of that year. The hourly minimum wage was next raised to $\$ 4.75$ in October 1996 , and finally to $\$ 5.15$ in September 1997.

${ }^{v}$ Multivariate correspondence analysis cannot be applied to continuous variables, which is the case of many of the demographic variables, unless they are categorized.

${ }^{v i}$ The third component explains 10.72 percent of the variability, and opposes tenure and union status to veteran status.

${ }^{v i i}$ Pension benefits comprise 7.4 percent of total compensation in the public sector and 3 percent in the private sector, according to the BLS.

${ }^{\text {viii }}$ Since Social Security, a plan financed jointly by employers and employees, is nearly universal among workers in both sectors it has been excluded from the analysis.

${ }^{\text {ix }}$ There are three main types of formulas namely flat dollar amount, career earnings and terminal earnings. The flat dollar amount specifies a rate per year of service, which is multiplied by the number of years worked, and is

independent from employee earnings. In the career earnings formula benefits are obtained by multiplying a percentage of each year's earning times the years of service. In the terminal earnings formula, most common one, a percentage of the average earning in the final 3 or 5 years is used to compute the benefits. For more information about pension plans see Lovejoy (1988).

${ }^{\mathrm{x}}$ For the purpose of the MCA the variables SIC and VAC were categorized as follows: for sick leave (SIC): up to 3 days (1), between 3 and 8 days (2), more than 8 days (3); for paid vacations (VAC): up to 2 weeks (1), between 2 and 4 weeks (2), more than 4 weeks (3). Table 6 indicates that public sector workers receive twice as many paid sick leave days as private sector workers. On average workers at the public sector enjoy more weeks of paid vacation. However, 
the incidence of paid vacations is different between the two sectors. Wiatrowski (1988) finds that paid vacations are granted to almost all private workers, but only to 75 percent of public workers.

${ }_{\mathrm{xi}}$ Since MCA is based on qualitative variables, the variable wage needed to be categorized as follow: less than $\$ 6 /$ hour (1), between $\$ 6$ and $\$ 15 /$ hour (2) more than $\$ 15 /$ hour (3).

xii This information applies only to state and local governments together. No disaggregate information by level of government was available. The total benefits include paid sick leave, paid vacation, insurance, retirement,

supplemental pay, legally required benefits and other benefits such as severance pay and supplemental unemployment benefits.

\section{NOTES}

